line)

Regina Veckalne,

Riga Technical University, Latvia

(D) ORCID ID, 0000-0003-2517-1749

email: regina.veckalne@edu.rtu.lv

Tatjana Tambovceva,

Professor, Riga Technical University, Latvia

(C) ORCID ID, 0000-0002-9516-1530

email: tatjana.tambovceva@ritu.lv

Correspondence author: tatjana.tambovceva@rtu.Iv

\title{
INNOVATIONS IN CIRCULAR ECONOMY FOR SUSTAINABLE URBAN DEVELOPMENT
}

Abstract. In the past three decades, the concept of sustainable development became the focus of attention in practically all developed and developing countries. This concept aims to balance various economic, ecological, and social aspects that form the key pillars of sustainability. Notwithstanding the growing literature on sustainability, it is still unclear what components impact it. This paper summarizes and systematizes contemporary theoretical and methodological approaches to sustainable development and reviews urban sustainability factors mentioned in the literature to identify which ones are the most common and considered to be the most important. The authors analyzed the theoretical and practical foundations of the circular economy as a relatively new trend in sustainable urban development. Through the literature analysis, this paper concluded that the factors mentioned the most are related to the traditional three pillars of the sustainability model. Overall, 14 factors have been identified and packed into 4 groups: social factors, environmental factors, economic factors, and awareness factors. The research made it clear that the circular economy concept keeps evolving. It could be useful for achieving higher levels of urban sustainability through impact on some of the key urban sustainability factors. The achievement of sustainable development goals is reached within the general modernization processes observed in the economy and society. The technological and managerial innovations currently being implemented take into account the social, economic, and ecological needs of different subjects to the economy. This research paper is limited by its reliance on other scholars' self-reporting results of their studies. The results of this study could be used for further research in this field and perform as a foundation of achieving sustainable development on different levels of management through circular business models, recycled raw materials market, and management of circular production and consumption.

Keywords: sustainability, urban sustainability, sustainable development, sustainable cities, sustainable urban development, circular economy.

Introduction. The sustainability of urban areas has become an increasingly topical concern in the past few decades due to the ever-growing spread of urbanization across the globe (Wu, 2014). Indeed, in 2018 over half of the world's population lived in urban areas. Besides, this number is expected to reach 68 percent by 2050 (UN, 2018). While cities are portrayed as innovation hubs and centers for cross-cultural collaboration, their ecological footprint is extended far beyond their physical boundaries, leading to drawbacks in social and economic aspects within these urban centers and between them (Keiviani, 2010). Therefore, many scholars and practitioners seek to find and implement strategies that would help shrink the impact of cities on the planet while simultaneously improving the quality of life for the current and future generations. Because the concerted efforts to achieve urban sustainability are given, it is important to set goals and targets to track the progress towards urban sustainability outcomes. Therefore, a clear sustainability assessment methodology should be developed. Urban sustainability is one among many

Cite as: Veckalne, R., \& Tambovceva, T. (2021). Innovations in Circular Economy for Sustainable Urban Development. Marketing and Management of Innovations, 4, 196-209.

196 http://doi.org/10.21272/mmi.2021.4-15 
topic areas to which sustainability assessment is applied. However, the growing number of various methods of such assessment leads to an ambiguity of the existing measurements. This paper seeks to analyze the concept of sustainable urban development, which is the first step towards systematizing sustainability assessment methods. It examines the use of the circular economy model to achieve it. This research does so through a literature review on urban sustainability to meet the following objectives:

1. To analyze which factors affect sustainable urban development.

2. To report on general themes and trends in sustainable urban development literature.

3. To report on recent developments in circular economy with their relation to urban sustainability.

About three decades ago, all the progressive countries started their quest towards the realization of ehe concept of sustainable development, which was proposed at the 1992 UN Conference on Environment and development. The title itself implies the concept of development that could be sustained in the long term. By many, this concept is understood as the balance between ecologic, economic, and social aspects. Strong interest in and increasing topicality of this concept caused numerous interpretations and approaches to be created. The scientific interpretation of sustainable development requires the identification of the studied object. According to many scholars, it is the socio-ecological-economic system. In this case, «sustainable development» represents the balanced development that could be characterized by a high level of adaptation to the influence of different inner and outer factors and its ability to satisfy various private and public needs in the long run (Moraga, 2019). This approach takes into consideration the dynamics as well as the versatility of sustainable development. Sustainability is an endeavor to lift global living standards while respecting and protecting the Earth (Dearing et al., 2014; Steffen et al., 2015). Following this logic, sustainable cities are urban areas, the surroundings of which are planned and managed to provide livelihood and equity to the citizens while avoiding pressuring the environment beyond the key threshold. Cities being complex systems that are nested within unique ecological systems, each one being defined by its own historical and cultural context, make it extremely challenging to adequately select some out of a wide variety of factors that directly or indirectly influence urban sustainability (Gonzales et al., 2011). In this paper, the authors analyzed are the most mentioned in the literature factors. Preside attention is paid to the circular economy concept, which is lately actively developing across the globe.

Literature Review. By the end of the 20th century, diverse ideas from various movements, such as social justice, internationalism, and conservatism, had united in the call for «sustainable development».

In Cambridge Dictionary, the term «sustainability» is defined as:

1) The quality of being able to continue over a while;

2) The quality of causing little or no damage to the environment and, therefore, could continue over a while.

In the universally known report «Our Common Future», The Brundtland Commission states that sustainability means meeting one's own needs without compromising the ability of the descendants to meet their needs. Environmentalism, economic development, and social equity are important constituents of sustainability, as natural, social and economic resources have to be considered. At the University of Alberta, sustainability has been defined as a process of living within limits of available resources while creating living systems that enable humans to thrive in perpetuity. The United States Environmental Protection Agency argued that sustainability is the study of how natural systems function and remain diverse while producing everything the ecology needs to remain in balance, using the resources responsively to sustain the modern way of life. Sustainability is not limited to environment preservation. It is also closely linked to human health as a society, ensuring that neither a person nor an area of life suffers due to poor environmental legislation. Additionally, sustainability should cover the long-term effects of the action's humanity takes and find ways to improve both such actions and their consequences. 
A proposal to overcome social and environmental problems associated with the rapid worldwide urbanization process has been developed within the concept of urban sustainability. Over time, this urban sustainability was conceptualized in many other ways. They are reflected in various interdisciplinary approaches to it, including smart-growth frameworks focusing on compact, multi-use urban design and structure; biophilic ideas, zero-impact approaches aiming to achieve resource through technology; biocultural diversity, and nature-based solutions concentrate on ecosystem services, mimicry of nature, etc. Moreover, there are also approaches centered on creating environmentally-just cities, fair distribution of environmental benefits, and meaningful integration of underrepresented groups in the decision-making process. Some interdisciplinary frameworks tried to conceptualize urban sustainability and therefore propose different pathways to the concept of sustainable urban development (Jepson and Edwards, 2010; Elmqvist et al., 2019). The proposal of smart growth concentrates on compact multiuse dense urban structure and design (Wolff et al., 2019); nature-based solutions focus on ecosystem services, public health, and human wellbeing (Nesshoever et al., 2017); low and zero impact approaches emphasize resource efficiency achieved through technological advancement (Zaman et al., 2011); concepts of distributional, procedural and interactional justice and equity within sustainable development aim at achieving fair social structures and enhancement of social inclusiveness (Haase et al., 2017). Figure 1 presents the various urban sustainability approaches.

\begin{tabular}{|c|c|c|c|c|}
\hline $\begin{array}{c}\text { Planed Oriented } \\
\text { Approaches }\end{array}$ & $\begin{array}{l}\text { Greening and Eco- } \\
\text { Oriented City } \\
\text { Approaches }\end{array}$ & $\begin{array}{c}\text { Ecological/ } \\
\text { environmental system } \\
\text { based limits }\end{array}$ & $\begin{array}{c}\text { Social Justice } \\
\text { Oriented Approaches }\end{array}$ & $\begin{array}{c}\text { Sustainability } \\
\text { Management Oriented } \\
\text { Approaches }\end{array}$ \\
\hline $\begin{array}{l}\text { - New Urbanism } \\
\text { - Compact Cities } \\
\text { - Smart Growth } \\
\text { - Participatory } \\
\text { Planning }\end{array}$ & $\begin{array}{l}\text { - Ecosystem services } \\
\text { - Urban socio- } \\
\text { ecological systems } \\
\text { - Green infrastructure } \\
\text { - Nature-based } \\
\text { solutions }\end{array}$ & $\begin{array}{l}\text { - Ecological } \\
\text { footprint } \\
\text { - Energy } \\
\text { - Zero waste carbon } \\
\quad \text { pollution }\end{array}$ & $\begin{array}{l}\text { - Access and } \\
\text { participation in } \\
\text { decision making } \\
\text { - Inequitable } \\
\text { distribution of } \\
\text { environmental } \\
\text { bourdons and } \\
\text { access amenities }\end{array}$ & $\begin{array}{l}\text { - Goal setting } \\
\text { - Continuous } \\
\text { improvement } \\
\text { - Indicator } \\
\text { measurement }\end{array}$ \\
\hline
\end{tabular}

Figure 1. Different approaches to urban sustainability

Sources: developed by the authors.

The wide variety of approaches to urban sustainability implies different factors that influence the level of sustainability of urban development. Further, this paper analyzes these factors and tries to understand the most mentioned factors in literature sources. It also shows what factors are considered to be most important. The achievement of the sustainability goals could become possible only based on technological and managerial innovations, which are parts of the modernization processes in the society and the economy. Strategical directions of the development go hand in hand with the modernization theory, the concept of industrial revolutions, and technological progress. (Belik et al., 2019). Table 1 summarizes the types of economy, the industrial revolution, and the corresponding technological advancements.

The necessary for sustainable development technological advancements are important and only available during the primary modernization, which is related to the transition of traditional society to the industrial in the developing countries and the renewal of the industrial production base in the developed ones (da Costa Fernandes et al., 2020). Managerial innovations are prevalent during secondary modernization. The transition to post-industrial and information society aims to restructure the current economy, increase the production volume of items with higher added value, and decline raw materials exports. Primary modernization is often called new industrialization due to the development of the fourth and fifth technological paradigms. For the developed countries, primary modernization currently focuses 
on reshaping and reconstructing the national production based on the new technologies and business models.

Table 1. Types of economies, industrial revolutions, and related technological advancements

\begin{tabular}{|c|c|c|}
\hline $\begin{array}{c}\text { Type of } \\
\text { Economy }\end{array}$ & $\begin{array}{c}\text { Type of industrial } \\
\text { revolution/modernization }\end{array}$ & Characteristics of the technological paradigm \\
\hline $\begin{array}{l}\text { Pre-industrial } \\
\text { economy }\end{array}$ & $\begin{array}{l}\text { Absence of the industrial revolution, } \\
\text { underdevelopment of tools, need for } \\
\text { strong physical power }\end{array}$ & $\begin{array}{l}\text { Routine work, the main resource is humans' and } \\
\text { animals' muscular energy, need for physical efforts that } \\
\text { cause pain and suffering } \\
\text { The first industrial-technological paradigm is connected } \\
\text { with the mechanization of the textile industry. Key } \\
\text { resource - water energy. }\end{array}$ \\
\hline $\begin{array}{l}\text { Industrial } \\
\text { economy } 1.0\end{array}$ & First industrial revolution (XVIII-XIX) & $\begin{array}{l}\text { Second industrial-technological paradigm - usage of } \\
\text { steam and creation of railroads. Key resource - steam } \\
\text { energy, coal. The increase of industry scale could be } \\
\text { observed; the transport systems are developed. There } \\
\text { is steady emancipation of humans from hard physical } \\
\text { work. }\end{array}$ \\
\hline \multirow[b]{2}{*}{$\begin{array}{l}\text { Industrial } \\
\text { economy } 2.0\end{array}$} & \multirow{2}{*}{$\begin{array}{l}\text { Second industrial (technological) } \\
\text { revolution (XIX-XX) } \\
\text { The beginning of the primary } \\
\text { economic modernization }\end{array}$} & $\begin{array}{l}\text { The technological paradigm - steel, electricity, and } \\
\text { chemicals. Key resource - electricity. The concentration } \\
\text { of financial and bank capital, the appearance of radio } \\
\text { and telegraph, standardized production. Betterment of } \\
\text { the quality of life. }\end{array}$ \\
\hline & & $\begin{array}{l}\text { Forth technological paradigm - oil, automobile } \\
\text { production, mass production. Key resource - } \\
\text { hydrocarbon, nuclear energy. Mass and serial } \\
\text { production occur, and the development of } \\
\text { communication, transnational relations, and increased } \\
\text { production of goods. }\end{array}$ \\
\hline $\begin{array}{c}\text { Post- } \\
\text { industrial } \\
\text { economy } 3.0\end{array}$ & $\begin{array}{c}\text { Third industrial } \\
\text { (technological/scientific/ digital) } \\
\text { revolution }(X X-X X I)\end{array}$ & $\begin{array}{l}\text { Fifth technological paradigm - the era of information and } \\
\text { telecommunication. Key resource - atomic energy. The } \\
\text { production and consumption are individualized. With the } \\
\text { spread of globalization, transportation and } \\
\text { communication are improved. }\end{array}$ \\
\hline \multirow[t]{2}{*}{$\begin{array}{l}\text { Industrial } \\
\text { economy } 4.0\end{array}$} & \multirow{2}{*}{$\begin{array}{l}\text { The beginning of secondary } \\
\text { economic modernization. Fourth } \\
\text { industrial revolution. }\end{array}$} & $\begin{array}{l}\text { Sixth post-industrial paradigm - nano- and bio- } \\
\text { technologies. Individualization of production and } \\
\text { consumption, the rapid decrease of production volumes, } \\
\text { and construction of materials with preset qualities. Life } \\
\text { expectancy is increased. }\end{array}$ \\
\hline & & $\begin{array}{l}\text { Seventh socio-humanitarian technological paradigm - } \\
\text { the era of metacognitive technologies, new } \\
\text { anthropology. }\end{array}$ \\
\hline
\end{tabular}

Sources: developed by the authors.

The secondary modernization is connected to establishing the information or digital economy, which is based on the sixth and seventh technological paradigms (Suarez-Eiroaa et al., 2019). This modernization was a consequence of the fourth industrial revolution. The first and the second industrial revolutions caused a mass negative impact on all the environmental elements through various types of pollution and depletion of natural resources. The third industrial revolution that led to new fields of activities, which do not imply mass usage of natural resources, decreased resource consumption; however, created the problem of an increasing volume of toxic computer technology waste (Prieto-Sandoval et al., 2018). 
The fourth industrial revolution, which is based on the concept of Industry 4.0 - used as a part of the German national program to create automatized interaction with external production lines, releasing individualized products, while slowly penetrating the world, providing the conditions for more rational production (Ghobakhloo, 2020). The fourth industrial revolution is directly connected to the sixth technological paradigm. It enables a better quality of life, a transaction to new technology, and a new economy model (Yadav, 2020). The results of the fourth industrial revolution and the sixth technological paradigm comport the concept of the green economy, which is supposed to pave the way for realizing sustainable development goals. The UN report «Towards a Green Economy» characterizes this type of economy as the one that increases the nation's wealth and provides social equity while simultaneously reducing the risks for the environment (UNEP, 2011). It is supposed to replace the so-called «brown» economy that is highly dependent on fossil fuels and causes natural resource depletion and social marginalization. According to the report, the key economic growth and development resources are renewable energy, energy-efficient buildings, transportation systems with low $\mathrm{CO} 2$ emission, production of «clean» automobiles, waste management systems, etc. Besides, this document presents 10 main sectors that should be prioritized for private and public green investments - construction, energy, forestry, tourism, waste recycling, utilization, etc.

Table 2. Features of the green economy development

\begin{tabular}{|c|c|c|c|}
\hline $\begin{array}{l}\text { Comparison } \\
\text { criteria }\end{array}$ & $\begin{array}{c}\text { Clean production } \\
\text { concept }\end{array}$ & $\begin{array}{c}\text { Best available } \\
\text { techniques concept }\end{array}$ & Circular economy \\
\hline $\begin{array}{l}\text { Active development } \\
\text { period }\end{array}$ & 1990's & 1990's & $2012-2015$ \\
\hline Key ideas & $\begin{array}{l}\text { Prevention of toxic } \\
\text { emissions, creation of } \\
\text { safe products }\end{array}$ & $\begin{array}{l}\text { Implementation of } \\
\text { existing technologies, } \\
\text { which are ecologically } \\
\text { and economically } \\
\text { efficient }\end{array}$ & $\begin{array}{c}\text { Formation of the economy that } \\
\text { is based on the principles of } \\
\text { reuse and recycles }\end{array}$ \\
\hline $\begin{array}{l}\text { Type of } \\
\text { technological } \\
\text { innovations }\end{array}$ & $\begin{array}{l}\text { Creation of waste-free } \\
\text { (energy-saving) and } \\
\text { ecologically safe } \\
\text { technologies }\end{array}$ & $\begin{array}{l}\text { Formation of the best } \\
\text { technologies in terms of } \\
\text { ecology and } \\
\text { environment }\end{array}$ & $\begin{array}{c}\text { Creation of circular } \\
\text { technologies that provide } \\
\text { cyclical rotation of } \\
\text { technological and biological } \\
\text { materials }\end{array}$ \\
\hline $\begin{array}{l}\text { Type of managerial } \\
\text { innovations }\end{array}$ & $\begin{array}{l}\text { Development and } \\
\text { implementation of clean } \\
\text { production programs in } \\
\text { businesses }\end{array}$ & $\begin{array}{l}\text { Formation of ecological } \\
\text { management in } \\
\text { businesses }\end{array}$ & $\begin{array}{l}\text { Implementation of circular } \\
\text { business models, methods of } \\
\text { cyclical production, and } \\
\text { consumption managements }\end{array}$ \\
\hline $\begin{array}{l}\text { Key economy } \\
\text { sectors }\end{array}$ & $\begin{array}{l}\text { Construction, energy, } \\
\text { production, transport, } \\
\text { waste disposal }\end{array}$ & $\begin{array}{l}\text { Agriculture, construction, } \\
\text { energy, production, } \\
\text { water resources, and } \\
\text { waste disposal }\end{array}$ & $\begin{array}{l}\text { Agriculture, construction, } \\
\text { energy, fishery, forestry, } \\
\text { production, tourism, transport, } \\
\text { water resources, and waste } \\
\text { management }\end{array}$ \\
\hline
\end{tabular}

Sources: developed by the authors.

In this research, the authors have explored the umbrella concept of the green economy. It covers various aspects of sustainable development, such as clean production, state-of-art technologies, and circular economy, which offer rational models of production and consumption. The concepts above are related to the current technological and managerial advancements portrayed as effective mechanisms of ecological modernization that set the directions for green investments. 
Methodology and research methods. This study aims to identify the key factors influencing the sustainability level of urban development. The authors used a systematic literature review on urban sustainability, following Preferred Reporting Items for Systematic Reviews and Meta-Analysis (PRISMA) guidelines (Moher et al., 2009). After the literature search, content analysis has been employed to organize qualitative data to examine what factors influence urban sustainability. The search terms «sustainability», «sustain», «urban», "community», «factor», «indicator» were used in SCOPUS, Web of Science and Science Direct. These sources were used as they are large search systems that employ multiple databases. The timeframe applied was 2001-2020. Such a data range was employed to narrow down the results to the articles published after sustainability science was identified as a unique discipline (Kates et al., 2001). The authors only considered peer-reviewed articles that were published in English. While the main focus was on the articles related to urban sustainability, some articles providing information about factors impacting sustainability, in general, were also considered. In total, 2134 articles have been identified. The reviewed articles included papers on urban sustainability development with case studies from around the globe. Although the diversity of cases worldwide can lead to confusion during analysis, regional differences are clearly valuable and thus should not have been excluded. Whilst cities across the globe may face different challenges to their individual contexts. There is value in reading broadly across all the available case studies (Cohen, 2017).

Once 31 literature sources were selected for inclusion, every single source was read in full for qualitative content analysis. Information related to urban sustainability was recorded in a spreadsheet, organized by columns for categories identified by the authors. Notwithstanding the efforts to systematize a set of studies on urban sustainability and identify factors affecting it, this study has several limitations. First of all, the selection of literature is limited to the papers found by the selected databases. Second, the content analysis was produced based on the findings and interpretations of other authors, and there is little room to control the biases that may have occurred in those studies. However, this research still demonstrates a broad reading of the literature and combines reported by other factors by categories.

Table 3 demonstrates the articles included in the analysis. Some of the papers did not include empirical data, as they were purely theoretical. Such articles were noted as "not spatially explicit" in the column "Locations".

Table 3. Included literature for the systematic review $(n=28)$

\begin{tabular}{|c|c|c|c|}
\hline $\mathbf{N}$ & Source & Topic & Location \\
\hline 1 & Kotharkar et al. & Measurability for Sustainable Urban Development & India \\
\hline 2 & Ali-Toudert et al. & $\begin{array}{l}\text { Comprehensive Assessment Method for Sustainable Urban } \\
\text { Development }\end{array}$ & Germany \\
\hline 3 & Cavric et al. & Measuring Sustainable Urban Development & Croatia \\
\hline 4 & Rosales & Modeling of sustainability into urban planning & Mexico \\
\hline 5 & $\begin{array}{l}\text { Lopez- } \\
\text { Carreiro\&Monzon }\end{array}$ & Evaluating sustainability and innovation of mobility & Spain \\
\hline 6 & Haidera et al. & $\begin{array}{l}\text { Sustainability assessment framework for small-sized urban } \\
\text { neighborhoods }\end{array}$ & $\begin{array}{l}\text { Canada, } \\
\text { Saudi Arabia }\end{array}$ \\
\hline 7 & Stanislava\&Chin & $\begin{array}{l}\text { Evaluating livability and perceived values of sustainable } \\
\text { neighborhood design }\end{array}$ & USA \\
\hline 8 & Saeza et al. & Sustainable city rankings, benchmarking and indexes & Spain \\
\hline 9 & Reid\&Rout & Developing sustainability indicators & New Zealand \\
\hline 10 & Alpopi et al. & $\begin{array}{l}\text { Assessment of the sustainable urban development level through the } \\
\text { use of indicators of sustainability }\end{array}$ & Romania \\
\hline 11 & Li\&Yi & Assessment of city sustainability & China \\
\hline 12 & Chatzimentor et al. & A review of green infrastructure research in Europe & Greece, UK \\
\hline
\end{tabular}


Continued Table 3

\begin{tabular}{|c|c|c|c|}
\hline $\mathbf{N}$ & Source & Topic & Location \\
\hline 13 & Maranghi et al. & $\begin{array}{l}\text { Integrating urban metabolism and life cycle assessment to analyze } \\
\text { urban sustainability }\end{array}$ & Sweden, Italy \\
\hline 14 & Laslett \& Urmee & The effect of aggregation on city sustainability rankings & Australia \\
\hline 15 & $\begin{array}{l}\text { Rodrigues\&Franc } \\
0\end{array}$ & $\begin{array}{l}\text { Measuring the sustainable urban development in cities through a } \\
\text { Composite Index }\end{array}$ & Portugal \\
\hline 16 & Kamino et al. & Improving the sustainability assessment method SBTool Urban & Portugal \\
\hline 17 & Gong et al. & $\begin{array}{l}\text { Sustainable Urban Development System Measurement Based on } \\
\text { Dissipative Structure Theory, the Grey Entropy Method and } \\
\text { Coupling Theory }\end{array}$ & China \\
\hline 18 & $\begin{array}{l}\text { Larimian \& } \\
\text { Sadeghi }\end{array}$ & $\begin{array}{l}\text { Measuring urban social sustainability: Scale development and } \\
\text { validation }\end{array}$ & $\begin{array}{l}\text { UK, New } \\
\text { Zealand }\end{array}$ \\
\hline 19 & EU Report & Indicators for Sustainable Cities Environment & EU \\
\hline 20 & Ahern et al. & $\begin{array}{l}\text { The Concept of Ecosystem Services in Adaptive Urban Planning } \\
\text { and Design }\end{array}$ & USA \\
\hline 21 & Bravo et al. & $\begin{array}{l}\text { Trade-offs among urban sustainability, pollution and livability in } \\
\text { European cities. }\end{array}$ & Spain \\
\hline 22 & Steiniger et al. & Localizing urban sustainability indicators & Chile \\
\hline 23 & Gao et al. & $\begin{array}{l}\text { Viewpoint: A correction to the entropy weight coefficient method by } \\
\text { Shen et al. for accessing urban sustainability }\end{array}$ & China \\
\hline 24 & Atshan et al. & $\begin{array}{l}\text { Pathways to urban sustainability through individual behaviors: The } \\
\text { role of social capital }\end{array}$ & USA \\
\hline 25 & Buzasi \& Jaeger & District-scale assessment of urban sustainability & Hungary \\
\hline 26 & Kong et al. & A systematic review of big data-based urban sustainability research & $\begin{array}{l}\text { Not spatially } \\
\text { explicit }\end{array}$ \\
\hline 27 & Gaubatz \& Hanink & Chinese Cities as Urban Sustainability Laboratories & China \\
\hline 28 & Yang et al. & $\begin{array}{l}\text { Evaluating urban sustainability under different development } \\
\text { pathways }\end{array}$ & China \\
\hline
\end{tabular}

Sources: developed by the authors.

A plurality of studies organized urban sustainability factors around the traditional "three pillars» (ecology, economy and society). Overall, the authors managed to identify 15 different factors that are thought to influence sustainability in the context of urban development (Figure 2). Those factors could be grouped based on their features.

The first group represents one of the traditional pillars of sustainability - the economy. It includes such factors as economic growth, which is mentioned in 16 sources; employment, mentioned in 8, and economic vibrancy - stated in 5 articles. Economic vibrancy is characterized by dynamic changes in the market that involve new types of opened firms, newly introduced services, new solutions, etc. It is basically diversification in the market, provided that there are strong competitors in different economy segments. Essentially, it also includes the concept of entrepreneurship, which indeed was also mentioned in the literature several times.

The second group of factors goes under the «social pillar» with factors like social justice with 13 instances in the literature, health with 9 instances, culture and traditions and quality of life -8 instances each, and finally safety, the factor that was mentioned 6 times in the reviewed articles. The «environment pillar» group is made up of the following two factors: environmental quality and preservation (19 references) and resources (16 references).

Another important factor, which clearly influences the level of sustainability, is infrastructure. Eight scholars stated it. However, it is believed to play an indisputable role in forming so-called sustainable 
cities. Access to public transport, schools, and kindergartens in the neighborhood, green areas for leisure activities are the elements that promote sustainable habits within the society.

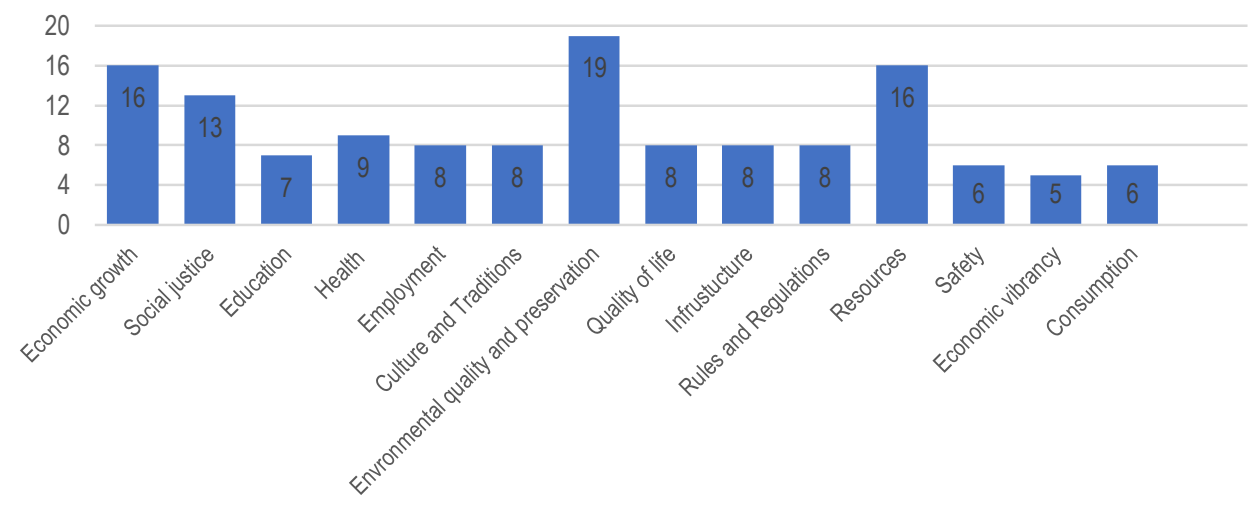

Figure 2. Factors affecting the level of sustainability of urban development

Sources: developed by the authors.

Speaking of habits, the behavior of citizens is another significantly influential factor when it comes to urban sustainability. However, it has only been mentioned once in the reviewed literature. The authors would like to introduce another category named «awareness» to those mentioned above based on three pillars of sustainability groups. This one would include education (7 references); rules and regulations (8 references), and consumption (6 references). Although each of the categories mentioned above could have been included in society-ecology-economy groups, we think it is vital to separate them. Why is it important, and why is it called «awareness»? First of all, despite all the attempts to make sustainability a topical issue, many people, especially from the developing and underdeveloped countries, are not quite familiar with the term up until today. And to many of those who are familiar, it is mostly limited to environmental issues (NIM, 2015). This study has included the «education» factor into this category. The idea and concepts of sustainability should become a part of the educational process and not only at a higher level institution among those students who chose sustainability-related fields as their major but rather start at the very beginning of the school journey. Thus, the educational factor should go hand in hand with the awareness.

Secondly, the authors included «rules and regulations» (8 references) into the «awareness» category. Many people find out about the country's challenges and problems once they are being discussed at the legislation level. If the country implements some laws regarding sustainability practices, the behavior of citizens would need to change to comply with the law. Still, also more people would start questioning unsustainable practices present in the environment. Last but not least, it was added consumption with its 6 instances in the reviewed literature. Consumption has a direct impact on the sustainability level of the city. However, it itself is dependent on the awareness level of citizens, among other factors. People tend to change their consumption habits once they become aware of their negative influence on future generations. It is known that lack of awareness and growing consumption level lead to alarming waste across the globe. Since most of the waste is not recycled nowadays, it ends up in landfills, burned or dumped in the ocean, creating entire waste isles. Therefore, it is necessary to turn to the concept of the circular economy to address this issue. 
Results. A specific feature of the concept of environmentally friendly production (or cleaner production), which was developed in the 1990s in the USA and some European countries, focuses on the logical completion of replacing with environmentally friendly technologies that include several stages. Endof-pipe technology - an «environmental supplement» to the main technology is a low-waste, resource- and energy-saving technology. It aims at the maximum possible prevention of emissions and discharges of pollutants and wastes in places of their origin, integrated use of natural resources, and the creation of safe products (Rossi et al., 2020). According to the environmentally clean production supporters, the implementation of green technological innovations within businesses could be promoted by such organizational management innovation, as the development and implementation of an environmentally cleaner production, which should be implemented primarily in industrial enterprises, as well as in organizations involved in the construction, energy, and transport (Kristensen, 2020). Meanwhile, the active development of the waste disposal sector is expected.

The circular economy concept is the youngest among all the concepts mentioned above. It was presented in the joint report of the World Economic Forum and McKinsey \& Company. This concept is aimed at the transition from the linear economy characterized by the algorithm of resource extractionproduction-waste disposal to the circular economy, the principle of which is to recycle and reuse the consumed resources (World Economic Forum, 2014). This concept offers the consolidation of earlier proposed technological advancements. Unlike other green economy directions, it introduces various tools for managerial innovations and could be realized in all the key economic sectors.

The concept of circular economy aims to prioritize cyclical rotation of technical and biological materials. Cyclical rotation of the biological (organic) materials implies that they should be returned to the environment without being damaged. Cycles of the material allow continuous turnover in production through reuse, recycling, and modification, enabling the rational employment of natural resources.

The key areas in the circular economy research are sustainable development within industrialization and urbanization, management of the product life cycle to reduce waste, eco production, landscaping logistics. Data that form circularity in the production are gathered through the system, which helps determine where the product comes from, how it was produced, and how much energy was used to produce it. This information helps firms, cities, and countries renew and rebase the resources more efficiently. Unlike a multi-dimensional and mostly abstract concept of sustainable development, the concept of circular economy aims to regulate ecologic economic systems, which are characterized by various forms of interaction between economy and environment (De Angelis, 2020). Figure 3 demonstrates the interaction of different economic activities related to the four stages of the production cycle with the environment. It is important to consider the social aspect, as the acceptance of the idea of the circular economy largely depends on the level of eco-awareness in society and the eagerness to take responsibility for one's actions. Ellen McArthur Foundation has developed five circular business models that focus on implementing the technologies, which promote using fewer resources for goods and services production, prolonging the life-cycle of the existing products, and recycling. These models are presented above:

1. Circular suppliers: this business model suggests transactions from nonrenewable resources to renewable.

2. Resources' recovery: this model focuses on waste utilization through recycling, regeneration, recuperation, and energy utilization (using solid waste as an energy source).

3. Product life extension: this is achieved through repair, modernization, reconstruction, and renewal of products.

4. Sharing platforms: this model promotes the creation of platforms for interaction among product users for exchange and shared use of products.

5. Product as service: instead of buying the product, this model suggests leasing it. 


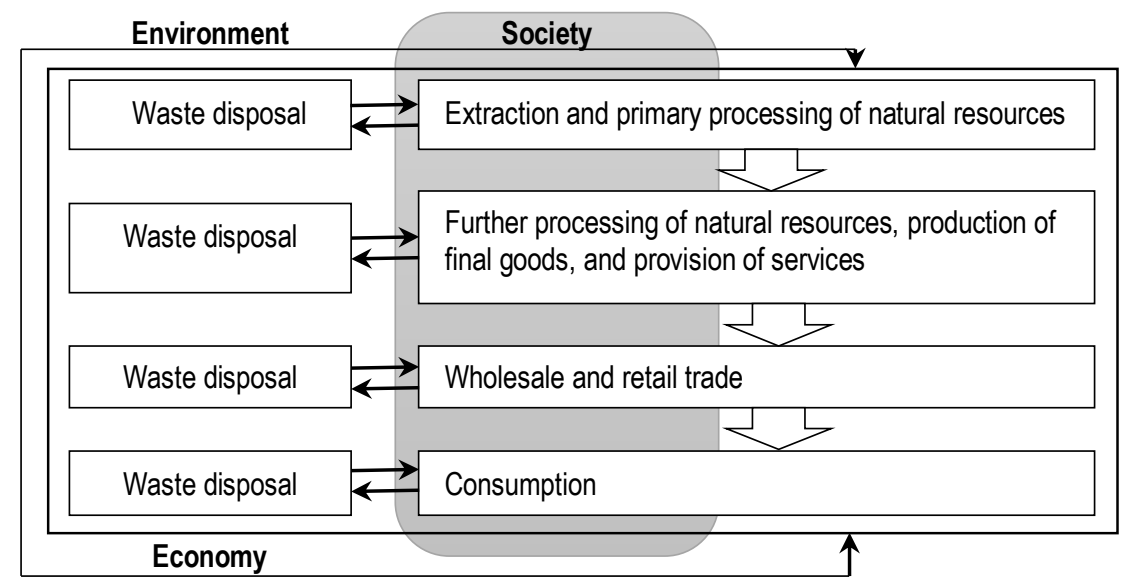

Figure 3. Interaction of the economy, environment, and society from the perspective of circular

Sources: developed by the authors. economy

These models can be either used separately or together. First and foremost, they aim to the microeconomic level of circular economy implementation. Nevertheless, they could also be used at other levels of economic management. Figure 4 demonstrates how the circular business models and main types of economic activities are connected to the levels of implementing the circular economy concept. The development of the circular economy concept could be observed from the point of expansion of $\mathrm{R}$, which is a core of the hierarchy of circular management of production and consumption. Originally it was presented as $3 R$ - reduce, recycle and reuse.

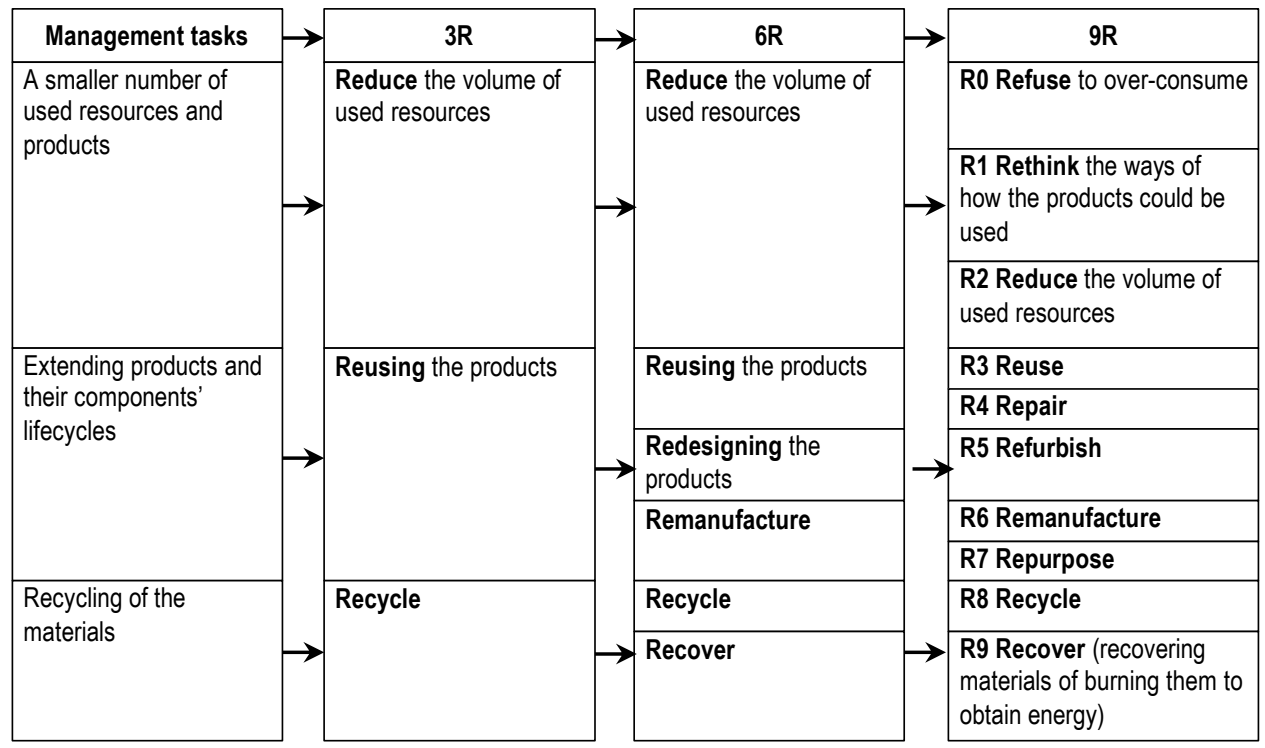

Figure 4. The development of the circular economy concept from the "R" point of expansion Sources: developed by the authors. 
Reduction of resources used in the production means using less energy, materials, and other resources needed for production purposes and waste minimization while using the product, which helps achieve a maximum level of circularity. Reuse implies repeated use of the final good and its components after the first life-cycle had been completed, which causes a decrease in the volume of primary resources and materials in the following cycles. Finally, recycling implies transforming waste into new materials, products, or energy sources. Then, considering all the lifecycle stages, $2 R$ was updated to $6 R$ by adding recovery, redesign, and remanufacture (Houshyar et al., 2014). Recover is a process of collecting materials and using products again in the following stages of the life cycle or recovering to the initial condition. The redesign is a process of next-generation product development in which the components from the previous lifecycle are used without loosing the functionality of the new items. Remanufacture is the production of new products using old (used) materials. When adding types of organization of smartconsumption, the scheme expands to 9R (Potting et al., 2017), which includes refusing (a refusal to overconsume), refurbish (renewal of old, but functioning good), repurpose (using non-functioning goods' components for other purposes), and repair (repair of old non-functioning product to extend its lifecycle).

So, considering the detected earlier factors that influence the level of sustainability of urban development, it could be concluded that many of them would have benefited from applying circular economy techniques. Obviously, consumption would be affected the most since 3-6-9 R's are aimed at changing society's consumption habits in the first place. People would be encouraged to buy less, extend products' lifecycles and finally, send the product for re-or upcycling when it could no longer be used. Factor "economic vibrancy» would also be significantly affected, as the circular economy brings a lot of new business models to the table. For instance, with the spread of circular economy trends worldwide, it was seen many new enterprises like zero-waste cafes and shops, factories, and brands that create fashion items from reduced plastic and organic waste, sharing platforms in forms of websites and mobile applications that make money from advertising and app-downloads. It means new opportunities for both entrepreneurs and the common public. Circular economy practices could also aid resources preservation, environmental quality, and quality of life. And of course, countries with higher circularity rates are better developed economically than those with a lower rate. It means that introducing circular economy practices could bring positive changes in the urban sustainability level by influencing the most important urban sustainability factors.

Conclusion. This paper reviewed the literature on urban sustainability to identify the most common impacting factors. The findings of the literature analysis allowed concluding that the factors mentioned the most are related to the traditional three pillars of the sustainability model. Overall, 14 factors have been identified and packed into 4 groups: social factors, environmental factors, economic factors, and awareness factors. The research made it clear that the circular economy concept keeps evolving. It could be useful for achieving higher levels of urban sustainability through impact on some of the key urban sustainability factors. The achievement of sustainable development goals is reached within the general modernization processes observed in the economy and society. The currently being implemented technological and managerial innovations consider the social, economic, and ecological needs of different subjects to the economy. This research is limited by its reliance on other scholars' self-reporting results of their studies. Moreover, there are language inconsistencies across various literature sources. Therefore, current analysis is based on own interpretations of what is at times unclear work of others. The perspective direction for further research could be the analysis of specifications of circular economy implementation in different segments of the economy and its effect on the factors mentioned above.

Author Contributions: conceptualization, T. T. and R. V.; methodology, R. V.; validation, R. V. and T. T.; formal analysis, R. V., and T. T.; investigation, R. V.; writing-original draft preparation, R. V. and T. T.; writing-review and editing, T. T.; visualization, R. V. and T. T.; supervision, T. T. 


\section{R., Veckalne, T., Tambovceva. Innovations in Circular Economy for Sustainable Urban Development}

\section{References}

Ahern, J., Cilliers, S., \& Niemelä, J. (2014). The concept of ecosystem services in adaptive urban planning and design: A framework for supporting innovation. Landscape and Urban Planning, 125, 254-259. [Google Scholar] [CrossRef]

Ali-Toudert, F., Ji, L., Fährmann, L., \& Czempik, S. (2020). Comprehensive assessment method for sustainable urban development (CAMSUD)-a new multi-criteria system for planning, evaluation and decision-making. Progress in Planning, 140, 100430. [Google Scholar] [CrossRef]

Alpopi, C., Manole, C., \& Colesca, S. E. (2011). Assessment of the sustainable urban development level through the use of indicators of sustainability. Theoretical and Empirical Researches in Urban Management, 6(2), 78-87. [Google Scholar]

Atshan, S., Bixler, R. P., Rai, V., \& Springer, D. W. (2020). Pathways to urban sustainability through individual behaviors: The role of social capital. Environmental Science \& Policy, 112, 330-339. [Google Scholar] [CrossRef]

Belik, I., Starodubets, N., Yachmeneva, A., \& Alikberova, T. (2019). Green growth diagnostics: regional aspect. Journal of Environmental Management \& Tourism, 10(3 (34)), 448-458. [Google Scholar] [CrossRef]

Buzási, A., \& Jäger, B. S. (2020). District-scale assessment of urban sustainability. Sustainable Cities and Society, 62, 102388. [Google Scholar] [CrossRef]

Chatzimentor, A., Apostolopoulou, E., \& Mazaris, A. D. (2020). A review of green infrastructure research in Europe: Challenges and opportunities. Landscape and Urban Planning, 198, 103775. [Google Scholar] [CrossRef

da Costa Fernandes, S., Pigosso, D. C., McAloone, T. C., \& Rozenfeld, H. (2020). Towards product-service system oriented to circular economy: A systematic review of value proposition design approaches. Journal of Cleaner Production, 257, 120507. [Google Scholarl [CrossRef

De Angelis, R. (2021). Circular economy and paradox theory: A business model perspective. Journal of Cleaner Production, 285, 124823. [Google Scholar] [CrossRef]

Dearing, J. A., Wang, R., Zhang, K., Dyke, J. G., Haberl, H., Hossain, M. S., ... \& Poppy, G. M. (2014). Safe and just operating spaces for regional social-ecological systems. Global Environmental Change, 28, 227-238. [Google Scholar] [CrossRef]

Elmqvist, T., Andersson, E., Frantzeskaki, N., McPhearson, T., Olsson, P., Gaffney, O., ... \& Folke, C. (2019). Sustainability and resilience for transformation in the urban century. Nature Sustainability, 2(4), 267-273. [Google Scholar] [CrossRef]

Forman, R. T., \& Wu, J. (2016). Where to put the next billion people. Nature, 537(7622), 608-611. [Google Scholar] [CrossRef]

Gaubatz, P., \& Hanink, D. (2020). Learning from Taiyuan: Chinese cities as urban sustainability laboratories. Geography and Sustainability, 1(2), 118-126. [Google Scholar] [CrossRef]

Gao, P., Wang, X., Wang, H., \& Cheng, C. (2020). Viewpoint: A correction to the entropy weight coefficient method by Shen et al. for accessing urban sustainability. Cities, 103, 102742. [Google Scholar] [CrossRef]

Ghobakhloo, M. (2020). Industry 4.0, digitization, and opportunities for sustainability. Journal of cleaner production, 252, 119869. [Google Scholar] [CrossRef]

Gong, Q., Chen, M., Zhao, X., \& Ji, Z. (2019). Sustainable urban development system measurement based on dissipative structure theory, the grey entropy method and coupling theory: a case study in Chengdu, China. Sustainability, 11(1), 293. [Google Scholar] [CrossRef]

Gonzalez, A., Donnelly, A., Jones, M., Klostermann, J., Groot, A., \& Breil, M. (2011). Community of practice approach to developing urban sustainability indicators. Journal of Environmental Assessment Policy and Management, 13(04), 591-617. [Google Scholar] [CrossRef]

Haider, H., Hewage, K., Umer, A., Ruparathna, R., Chhipi-Shrestha, G., Culver, K., .. \& Sadiq, R. (2018). Sustainability assessment framework for small-sized urban neighbourhoods: An application of fuzzy synthetic evaluation. Sustainable cities and society, 36, 21-32. [Google Scholar] [CrossRef]

Haase, D., Kabisch, S., Haase, A., Andersson, E., Banzhaf, E., Baró, F., ... \& Wolff, M. (2017). Greening cities-To be socially inclusive? About the alleged paradox of society and ecology in cities. Habitat International, 64, 41-48. [Google Scholar] [CrossRef]

Houshyar, A., Hoshyar, A., \& Sulaiman, R. B. (2014). Review paper on sustainability in manufacturing system. Journal of Applied Environmental and Biological Sciences, 4(4), 7-11.

Jepson Jr, E. J., \& Edwards, M. M. (2010). How possible is sustainable urban development? An analysis of planners' perceptions about new urbanism, smart growth and the ecological city. Planning Practice \& Research, 25(4), 417-437. [Google Scholar] [CrossRef]

Kamino, G., Gomes, S., \& Bragança, L. (2019). Improving the sustainability assessment method SBTool Urban-A critical review of construction and demolition waste (CDW) indicator. In IOP Conference Series: Earth and Environmental Science (Vol. 225, No. 1, p. 012004). IOP Publishing. [Google Scholar] [CrossRef]

Kates, R. W., Clark, W. C., Corell, R., Hall, J. M., Jaeger, C. C., Lowe, I., ... \& Svedin, U. (2001). Sustainability science. Science, 292(5517), 641-642. [Google Scholar] [CrossRef]

Keivani, R. (2010). A review of the main challenges to urban sustainability. International Journal of Urban Sustainable Development, 1(1-2), 5-16. [Google Scholar] [CrossRef]

Kong, L., Liu, Z., \& Wu, J. (2020). A systematic review of big data-based urban sustainability research: State-of-the-science and future directions. Journal of Cleaner Production, 123142. [Google Scholar] CrossRef 


\section{R., Veckalne, T., Tambovceva. Innovations in Circular Economy for Sustainable Urban Development}

Kotharkar, R., Bahadure, S., Bahadure, P., \& Surawar, M. (2011). Measurability for sustainable urban development: concept to application. ABACUS J. Archit. Conserv. Urban Stud, 7(2), 72-87. [Google Scholar]

Kristensen, H. S., \& Mosgaard, M. A. (2020). A review of micro level indicators for a circular economy-moving away from the three dimensions of sustainability?. Journal of Cleaner Production, 243, 118531. [Google Scholar] [CrossRef]

Larimian, T., \& Sadeghi, A. (2021). Measuring urban social sustainability: Scale development and validation. Environment and Planning B: Urban Analytics and City Science, 48(4), 621-637. [Google Scholar] [CrossRef]

Laslett, D., \& Urmee, T. (2020). The effect of aggregation on city sustainability rankings. Ecological Indicators, 112, 106076. [Google Scholar] [CrossRef]

Li, W., \& Yi, P. (2020). Assessment of city sustainability—Coupling coordinated development among economy, society and environment. Journal of Cleaner Production, 256, 120453. [Google Scholar] [CrossRef]

Lima, J. M., \& Partidario, M. R. (2020). Plurality in sustainability-Multipe understandings with a variable geometry. Journal of Cleaner Production, 250, 119474. [Google Scholar] [CrossRef]

Lopez-Carreiro, I., \& Monzon, A. (2018). Evaluating sustainability and innovation of mobility patterns in Spanish cities. Analysis by size and urban typology. Sustainable Cities and Society, 38, 684-696. [Google Scholar] [CrossRef]

Maranghi, S., Parisi, M. L., Facchini, A., Rubino, A., Kordas, O., \& Basosi, R. (2020). Integrating urban metabolism and life cycle assessment to analyse urban sustainability. Ecological indicators, 112, 106074. [Google Scholar] [CrossRef

del Mar Martínez-Bravo, M., Martínez-del-Río, J., \& Antolín-López, R. (2019). Trade-offs among urban sustainability, pollution and livability in European cities. Journal of Cleaner Production, 224, 651-660. [Google Scholar] [CrossRef]

Moher, D., Liberati, A., Tetzlaff, J., \& Altman, D.G. (2009). The PRISMA Group. Preferred reporting items for systematic reviews and meta-analyses: The PRISMA statement. PLoS Med., 6, 1-6.

Moraga, G., Huysveld, S., Mathieux, F., Blengini, G. A., Alaerts, L., Van Acker, K., ... \& Dewulf, J. (2019). Circular economy indicators: What do they measure?. Resources, Conservation and Recycling, 146, 452-461. [Google Scholar] [CrossRef]

Nesshöver, C., Assmuth, T., Irvine, K. N., Rusch, G. M., Waylen, K. A., Delbaere, B., ... \& Wittmer, H. (2017). The science, policy and practice of nature-based solutions: An interdisciplinary perspective. Science of the total environment, 579, $1215-1227$. [Google Scholar] [CrossRef]

Potting, J., Hekkert, M. P., Worrell, E., \& Hanemaaijer, A. (2017). Circular economy: measuring innovation in the product chain (No. 2544). PBL Publishers. [Google Scholar]

Prieto-Sandoval, V., Jaca, C., \& Ormazabal, M. (2018). Towards a consensus on the circular economy. Journal of cleaner production, 179, 605-615. [Google Scholar] [CrossRef]

Reid, J., \& Rout, M. (2020). Developing sustainability indicators-The need for radical transparency. Ecological Indicators, 110, 105941. [Google Scholar] [CrossRef]

Rodrigues, M., \& Franco, M. (2020). Measuring the urban sustainable development in cities through a Composite Index: The case of Portugal. Sustainable Development, 28(4), 507-520. [Google Scholar] [CrossRef]

Rosales, N. (2011). Towards the modeling of sustainability into urban planning: Using indicators to build sustainable cities. Procedia Engineering, 21, 641-647. [Google Scholar] [CrossRef]

Rossi, E., Bertassini, A. C., dos Santos Ferreira, C., do Amaral, W. A. N., \& Ometto, A. R. (2020). Circular economy indicators for organizations considering sustainability and business models: Plastic, textile and electro-electronic cases. Journal of Cleaner Production, 247, 119137. [Google Scholar] [CrossRef]

Saez, L., Heras-Saizarbitoria, I., \& Rodriguez-Nunez, E. (2020). Sustainable city rankings, benchmarking and indexes: Looking into the black box. Sustainable Cities and Society, 53, 101938. [Google Scholar] [CrossRef]

Suárez-Eiroa, B., Fernández, E., Méndez-Martínez, G., \& Soto-Oñate, D. (2019). Operational principles of circular economy for sustainable development: Linking theory and practice. Journal of cleaner production, 214, 952-961. [Google Scholar] [CrossRef]

Stanislav, A., \& Chin, J. T. (2019). Evaluating livability and perceived values of sustainable neighborhood design: New Urbanism and original urban suburbs. Sustainable cities and society, 47, 101517. [Google Scholar] [CrossRef]

Steffen, W., Richardson, K., Rockström, J., Cornell, S. E., Fetzer, I., Bennett, E. M., ... \& Sörlin, S. (2015). Planetary boundaries: Guiding human development on a changing planet. Science, 347(6223). [Google Scholar] [CrossRef]

Steiniger, S., Wagemann, E., de la Barrera, F., Molinos-Senante, M., Villegas, R., de la Fuente, H., ... \& Barton, J. R. (2020). Localising urban sustainability indicators: The CEDEUS indicator set, and lessons from an expert-driven process. Cities, 101 102683. [Google Scholar] [CrossRef] [Link]

UNEP. (2011). Towards a Green Economy: Pathways to Sustainable Development and Poverty Eradication. Retrieved from

Toplek, S., (2008). Measuring Sustainable Urban Development in Selected Coastal Cities of Croatia: an Indicator and GIS Based Approach for City of Zadar and Pula. Coastal Cities Summit, St. Petersburg, Florida, USA, 17-20 November, 2008 (June 2014), 0-16. Retrieved from [Link]

UN DESA. (2018). $68 \%$ of the world population projected to live in urban areas by 2050 , says UN. Retrieved from [Link]

Wolff, M., Haase, D., \& Haase, A. (2018). Compact or spread? A quantitative spatial model of urban areas in Europe since 1990. PLoS ONE, 13(2), e0192326. [Google Scholar] [CrossRef]

Wu, J. (2010). Urban sustainability: An inevitable goal of landscape research. Landscape Ecology, 25(1), 1-4. [Google Scholar] [CrossRef] 


\section{R., Veckalne, T., Tambovceva. Innovations in Circular Economy for Sustainable Urban Development}

WEF. (2014). Towards the Circular Economy: Accelerating the scale-up across global supply chains. Geneva: World Economic Forum. Retrieved from [Link]

Yadav, G., Luthra, S., Jakhar, S. K., Mangla, S. K., \& Rai, D. P. (2020). A framework to overcome sustainable supply chain challenges through solution measures of industry 4.0 and circular economy: An automotive case. Journal of Cleaner Production, 254, 120112. [Google Scholar] [CrossRef]

Yang, Z., Yang, H., \& Wang, H. (2020). Evaluating urban sustainability under different development pathways: A case study of the Beijing-Tianjin-Hebei region. Sustainable Cities and Society, 61, 102226. [Google Scholar] [CrossRef]

Zaman, A. U., \& Lehmann, S. (2011). Challenges and opportunities in transforming a city into a "zero waste city". Challenges, 2(4), 73-93. [Google Scholar] [CrossRef]

Регіна Вецкалне, Ризький технічний університет, Латвія

Тетяна Тамбовцева, професор, Ризький технічний університет, Латвія

Інновації циркулярної економіки для сталого розвитку міст

Метою статті є дослідження інновацій циркулярної економіки, що забезпечують досягнення цілей сталого розвитку, що розвиваються. Концепція сталого розвитку спрямована на забезпечення балансу між економічною, екологічною та соціальною сферами, які $є$ головними складовими сталого розвитку. Попри зростання наукового інтересу до означеної тематики, залишається невизначеним, яка зі складових має найбільший вплив на досягнення цілей сталого розвитку. У статті авторами систематизовано та узагальнено сучасні теоретичні та методологічні підходи до дослідження проблематики сталого розвитку, а також визначено найбільш суттєві та впливові фактори сталого розвитку міст. Авторами проаналізовано теоретичні та практичні основи циркулярної економіки, як відносно нового напряму сталого розвитку міст. За результатами теоретичного аналізу авторами зроблено висновок, що фактори, пов'язані з традиційною трикомпонентною моделлю сталого розвитку, $€$ найбільш згадуваними у наукових напрацюваннях. Загалом, було виявлено 14 факторів, які згруповано за 4 ознаками: соціальні, екологічні, економічні та інформаційні. Отримані результати засвідчили, що концепція циркулярної економіки продовжує розвиватись та сприяє досягненню вищого рівня сталості міст шляхом впливу на ключові фактори їх сталого розвитку. Досягнення цілей сталого розвитку має відбуватись шляхом модернізації економічних та соціальних процесів, а також імплементації технологічних та управлінських інновацій враховуючи соціальні, економічні, та екологічні потреби економічних суб'єктів. Отримані результати можуть бути використані для подальших досліджень означеної тематики, а також бути корисними для досягнення цілей сталого розвитку, популяризації циркулярних бізнесмоделей, ринку вторинної сировини, управління круговим виробництво та споживанням.

Ключові слова: сталість, сталість міст, сталий розвиток, сталі міста, сталий розвиток міст, кругова економіка. 